\title{
Aging in the Holy Scripture: The Human Responsibility for the Elderly Grounded On Ontology and Bioethics
}

Iosif Tamas ${ }^{1^{\star}}$, Camelia Tamas ${ }^{2}$, Anca Aginitei-Zbranca ${ }^{2}$ and Vladimir Poroch ${ }^{2}$

${ }^{1}$ Department of Roman-Catholic Theology, University of Alexandru Ioan Cuza, Iasi, Romania

${ }^{2}$ Grigore T. Popa University of Medicine and Pharmacy, lasi, Romania

*Corresponding author: Iosif Tamas, Department of Roman-Catholic Theology, University of Alexandru loan Cuza, lasi, Romania; E-mail: iosifta@yahoo.com

Received date: August 02, 2016; Accepted date: August 19, 2016; Published date: August 20, 2016

Copyright: (C) 2016 Tamas I, et al. This is an open-access article distributed under the terms of the Creative Commons Attribution License, which permits unrestricted use, distribution, and reproduction in any medium, provided the original author and source are credited.

\begin{abstract}
On September 28, 2014, the Holy Father Pope Francis, at the initiative of the Pontifical Council for the Family, participated in the day dedicated to the elderly. The meeting took place in "Saint Peter" market in Rome and was attended by tens of thousands of old people and grandparents with their families from many countries. Pope Benedict XVI emeritus being invited by Pope Francis also attended the meeting entitled "Blessing of a long life". It was also supported the position of bioethics, called to contrast the poisonous culture of the "rebut" that's been done a lot of harm to our world. The infants, the young (because they did not work), even the old claim to maintain a "balanced" economic system where not the person is to be found, but the money. We the Christians, together with all people of good will, are called to patiently build a different society: warm, human, inclusive, which does not need to throw the weak in body and mind, on the contrary, a society capable to measure its own "step" just according to the elderly. It is essential to pay attention to [...] more lonely and abandoned elderly. In this paper we follow the religious understanding of the old age in the light of The Holy Scripture (the long life and approaching death; the life experience and progress in wisdom; the old symbol of eternity), skin aging and the Church's position on the issue of elderly care, and explain how this palliative responsibility is ontological and bioethical grounded for the elderly and not someone else's interests.
\end{abstract}

Keywords: Bioethics; Aging; Responsibility; Body; Faith; Wisdom

\section{Introduction}

\section{Long life and approaching death}

A fact of life is that "years go by in a hurry" [1-5] and to live long becomes each man's desire who lives happily. Aging brings with it a wealth of life experience which also means gaining wisdom: “The years should talk and the multitude of months should learn to become wisdom" (Job 32.7) [6], but it [the old age] becomes burden for the man tormented by years who reached the limit of patience: "Why is light and life given to that in suffering, to the bitter soul"? (Job 3:20). So, the third age takes on another meaning, as it is conducted as a path of decline to death or like that of a rise to happiness and eternal life [7]. Life is a gift of God, even as "threatened" by death; a long life is desirable and promised to those who honored their parents: "Honor your father and mother, that your days may be long in the land which the Lord your God is given to you" (Ex 20.12). The blessed life is a crown for the righteous: "The fear of the Lord adds days, but the years of the guilty ones are shortened" (Prov 10,27), which will have the joy of seeing his children's children: "The elders' crown are their grandchildren, and the children's glory are their fathers" (Prov 17.6). Like Abraham at "full of days" (Gen 25.8) even the righteous, after a good and blossom old age: "They bring forth fruit in old age, retains its sap and freshness" (Ps, 92.15) can die in peace, knowing that his life was blessed: "He led him out and said: - Look to the sky and count the stars, if you can count them. And he said: - That will be your lineage" (Gen 15:15)," Tobit finished his words of thanks. [...] and was properly buried" (Tob 14.1-2). We should not expect a metaphysical reflection on human nature, on the man etc. from the old man of Israel. We find, however, a strong sense of his presence in life and a careful observation of the destiny. While they closely monitored the global destiny of the Covenant people, the elderly (wise men) were primarily interested in the person's life. They showed permanent human greatness and sensitive to human misery, to loneliness or fear in the face of pain (Job $7 ; 16)$ and death (Qoh, 3); at the impression of nothingness that is left by life or by the anxiety before an incomprehensible or absent God (Job, 10). We see death as a biological aspect, but we cannot naturally understand it because it contrasts the most deeply human instinct: life. Here's how the Council II of Vatican pronounces: "In the face of death the mystery of the human destiny reaches its peak. The man is not only tormented by suffering and progressive degradation of the body, but still more for fear of his final disappearance" [8]. And yet the key to solving the problem is in our hands for the older person that is in a state of dependency does not only need medical care, but above all to be treated with love [9].

\section{Life experience and progress in wisdom}

During their history the nations associated the age with the experience it brings. In the Bible the "elders" are at the forefront of the communities, "Go and gather the elders of Israel" (Ex 3:16). Even if some elderly were and are outrageously corrupt or unjust: "Three kinds of [people] hated my soul and I have been challenged by their lives: poor arrogant, rich old liar and adulterer, void of understanding" (Sir 25.2), however, the white hair deserved its respect: "Everyone must honor his father and mother" (Lev 19.32); "Do not rebuke the elder, but exhort him as a father" (1 Tim 5.1) and the children were taught to support the elderly and their parents: "Son, help your father when he is old and grieve him not in his life! "(Sir 3:12). Given the wisdom of the 
age (Sir 25.4, 32.3 Sir, Sir 42.8) in their capacity as witnesses of tradition, the elders can speak with authority. However, it would be better to do it with discretion and moderation as there is a danger that lurks them too, i.e.: instead of being open to the truth, to close to any novelty. The number of years is not enough to make the old one worthy of honor that is given. Moreover, wisdom may belong to youth: "I understand more than the ancients, because they keep your statutes" (Ps 119,100); "For old age does not mean the length of time measured by the number of years... But the dying righteous condemns the wicked living, and the youth soon reaching the perfection [condemns] long aging of the wicked" (Wis 4, 8.16) and to enter the kingdom, everyone must also receive it as a child: "I truly tell you, whoever does not receive the kingdom of God like a child shall not enter it" (Mar 10.15). The true wisdom comes from God. The mystery is that He gives the man a heart able to distinguish right from wrong: "Give your servant an obedient heart, as to judge thy people, discerning between right and wrong" (1Rg 3.9). But something happened: i.e. that all men, like their forefathers, always try the temptation to unfairly appropriate the divine privilege and to acquire through their own powers the knowledge of right and wrong: "God knows that in the day you taste of Him your eyes will be opened, and ye shall be as gods, knowing good and evil" (Gen 3.5). A vain wisdom lured them by the cunning serpent (Gen 3.1 ), identical to that of the scribes who judge everything according to human assessments and that exchanged the Law of Lord into a lie (Isaiah 29.15). The prophets will fight against wisdom of this type and their teaching will reject the temptation of self-sufficient humanism: human salvation comes only from God. The wise of the Holy Scripture is interested in the world around us. He admires it, and the faith leads him to see the mighty hand of God in it. What first interests him is to discover how to live his life to achieve true happiness. Wise is every man who puts into practice the art of living well. He observes the world with a lucid look, without illusions; he knows his limits, but that does not mean he also approves them. He knows what lies in the human heart, he knows what brings joy and pain but the wise does not stop as only having the role of observer. Being born educator, he traces the milestones for his disciples: prudence, moderation in desires, work and prayer bitterness, humility, thrift, temperance, sincerity in speech etc. The moral teaching of the Decalogue is translated into practical advice. No philosophy and no culture have a higher image of man than Judaism and Christianity [10]. The meaning of social life in the book of Deuteronomy and of the prophets inspires his advice on alms (Tob 4.7 to 11), to respect justice: "The false balance is abomination to the Lord, but the exact weight is His delight" (Prov 11, 1), love for the poor: "He who oppresses the poor and rejects the one who made him, but he who is kind to the needy honors Him" (Prov 14.31). He argues his words with the deeds of his past experience, but the deep inspiration comes over his experience. Once acquired the wisdom, with the price of a huge effort, the wise man does not want anything more than to convey peers and disciples (Sir 51.13 to 30), from one generation to the next [11], and urges to engage with courage to overcome the state of nature. Through the active participation in the spiritual perfection of creation, developing the way that the man is given by the surrounded status, the wise will know how to fertilize the seeds it contains. Our next problem and the only real problem is that of our ontological salvation in the midst of the "anthropological revolution", in which we are as humanity. This saving can be achieved with each assuming the roots of our lives with each closing to ourselves.

\section{Aging as a symbol of eternity}

Aging is, finally, the symbol of eternity. The eternal one appears to Daniel in the image of an old man "I beheld till the thrones were set and an old man sat. His clothes were like snow and his hair like pure wool. His throne was flames of fire and its wheels were burning fire" (Dan 7.9). In the Revelation Book the twenty-four elders symbolize the court of God who sings eternal glory (Rev 4.4; 5.14). Aging, in particular, is a time of grace in which God renews His call, to preserve and pass on the faith, to pray, to be next to the one in need. Grandparents have the ability to understand difficult situations: a great capacity! And when they are praying for these situations, their prayer is strong! The grandfather and grandmother who received the blessing of seeing their children's children (Ps 128.6) are assigned a greater mission, which is to convey the experience of life, the history of a family, a community, a nation. At this point the "dialogue between positivist sciences and humanities, which facilitates communication between bioethics and biotechnology in a way that would facilitate both disciplines support and mutually reinforcing" must be found [12]. The elders are obliged to share wisdom with simplicity and faith. Those families who have their grandparents close are happy. Grandfather is twice father and grandmother is twice mother. A nation who does not keep the old and who does not treat them properly has no future. Why has it no future? Because it loses the memory and detaches from its roots. When a man goes through suffering, this does not only affect the person's bodily dimension, but the person as a whole, which must therefore receive care in an integrated manner. "Respecting the person, physicians are committed to a high value in search for remedies and they are meeting the expectations and hopes of many patients in the world" [13]. We have a responsibility to keep alive the roots within ourselves by praying, works of mercy and proclaiming the Gospel. Thus, we remain as living trees, which in old age do not cease to bear fruit.

\section{Church and elderly care problem}

The church lies at the intersection of space and time in which different generations are called to answer God's loving plan. The exchange where the persons wear the moral social and religious values is a rich heritage for the family life and the world. Not always the elders have a family who can receive them. Then homes for the elderly are welcome... provided that they should be really houses, and not extermination sites, where the elders live there being forgotten, hidden, or neglected. And those should be done for the elderly, and not for someone else's interests. Homes for the elderly should be "lungs" of humanity in a country, in a neighborhood, or a parish; should be "sanctuaries" of humanity where the old and poor is cared and kept as a brother or big sister. It is much better to go and visit the old man [14]. But there is also the reality of elderly abandonment, when they are rejected with attitudes that are like a true hidden euthanasia. It is the effect of that culture of rebutting that does more harm to our world. The infants, the young are discarded, because they did not work, and the old one are discarded too claiming that a "balanced" economic system should be maintained where not the human person stands in the center, but the money. The church and all of us (as a society) are called to contrast this poisonous culture of scrap. We the Christians, together with all people of good will, are called to patiently build a different society, more welcoming, more humane, more inclusive, which does not need to throw the one who is weak in body and mind, on the contrary, a society which measures its own step just according to these people. As Christians and citizens, we are called to change, 
with fantasy and wisdom the roads to face this challenge. One of the nicest things of family life is to comfort a child and this to be comforted by a grandfather or grandmother. The future of a people necessarily implies this meeting: the young give strength to make people go and the elders strengthen this force by the memory and wisdom of popular culture.

\section{Skin aging}

During the last century due to the medical breakthroughs and the economic level growth, the population has higher living standards and the society hardly accepts skin aging and passing the time. The dermatologist finds him/herself in front of a pathological phenomenon: to consider the physiological aging as being abnormal and treat the consequences. Nowadays, skin benefits from care that would slow down the physiological pace of aging. Cosmetology has active principles that prevent, mitigate or slow its senescence marks. The dermatologist as a skin expert must find the scientific and particularly ethical substrate to slow physiological aging and change the aging appearance. [15] He must be a decision maker in education involved in the prevention of skin aging and its consequences. The correction of skin aging and its subcutaneous tissue is made by rejuvenating methods: (A) - dermatological and (B) - surgical.

(A) Dermatological methods: cosmetology (vitamin A derivatives), topical drugs (vitamin A derivatives, minoxidil, botulinum toxin), filled with hyaluronic acid, collagen or amino acids or physical methods (laser, pulse light, photo-modulation).

(B) Surgical methods: lifting, blepharoplasty, liposuction, micro grafts, and suspension wires.

An important aspect ignored by health authorities is the skin care for the elderly. In terms of public health, prevention costs less than treatment. It is known that the passage of time leads to weakening the supporting structure of the skin, loss of flexibility, breaking the barrier of skin by destroying the mechanical barrier of the acid layer. Once broken this barrier, cracks, ulcerations, bacterial, fungal and viral super-infections occur, and cells are more exposed to the UV and IR effects, with the formation of cancers that have skin cells as a starting point [16]. There are powerful active ingredients that may arise in maintaining a healthy skin: retinol, retinaldehide, vitamin $\mathrm{C}$, alpha hydroxyl acids, hyaluronic acid, natural or synthetic growth factors, antiradicalar actives, actives that act on adenosine. They must keep skin hydration by lipid surface reconstruction film NMF (natural moisturing factor), fight free radicals, activation of skin microcirculation and the act against proteolytic enzymes, of glycosylation phenomena, etc. This resulted in cosmetics against skin aging (also called "mature" skin), products whose effects are similar to drugs. In our country the health insurance does not compensate any care product for xerotic skin (although this type of skin is most common in old age) no disinfectant product for skin and no sunscreen product, so necessary to prevent skin cancers. The bioengineering researches, of pharmacologists and dermatologists take the lead in developing within laboratory of cloud-like structures or their cell layers, structures of maintenance or skin artificial filling. If at the beginning these structures aimed at replacing the damaged skin tissue by trauma, injury, burns, wide excision surgery with loss of skin then shortly due to increased youth without old age shall be given, dermatology and aesthetic dermatology used them in modifying the aesthetic appearance of the skin. There is a flexible highly ethical barrier between supply and demand. From an ethical point of view this barrier returns both on doctors (few physicians are able to refuse a patient who based on medical reasons does not have aesthetic dermatological treatments) and on drug manufacturers because the drug industry and medical devices have exorbitant and unjustified prices when they presents a product designed for rejuvenation. The handiest example is that of botulinum toxin and hyaluronic acid. For botulinum toxin, the same molecule, measured in units, designed to neurological treatments is 100 times cheaper than that for treatment of wrinkles, while for the hyaluronic acid, the same molecule, measured in milliliters is 50 times cheaper in rheumatology than aesthetic dermatology [17]. Facing this major price difference we wonder: is it ethical to slow down the physiological aging or is it ethical to have such a difference in price between the same types of drugs used for different destinations? This being the case it is required that the dermatologist or esthetician to acquire a thorough knowledge of physiology and of skin structure, of the techniques and medication for body and skin, along with knowledge on aesthetics, psychology and bioethics, in order to carry out the work when requested for skin rejuvenation or for skin care of the old people.

\section{Bioethical and ontological grounded palliative responsibility for elderly care}

The raising living standards, development of public health, progress in the medical sciences led to the aging of western society and thus to increase the life expectancy of the population. It is estimated a particular spread of this phenomenon so that over $53 \%$ of EU citizens will overcome 65 years old in 2050. However, the aging attracts a range of chronic diseases (cancer, dementia, degenerative neurological diseases, etc.) and the comorbidities that deeply affect the quality of human life. Cancer itself is a major public health problem globally by increasing incidence and the great burden exercised on health systems. It is estimated that up to 2050 there will be 24 million cases/year globally with 17 million in the developing countries (Parkin, Bray, Devesa). In the context of chronic, progressive diseases, of life limitation, when, unfortunately, the curative treatment is not often possible, the palliative care, bioethical and ontologically grounded, may be an alternative to control the symptom and a good quality of life. Care unit represents both the patient and his family, and the means by which these goals are achieved are represented by early identification, the impeccable assessment and treatment of pain and other symptoms, both physically, psychologically and spiritual. Knowing the requirements of the elderly person should contribute to community life, thus integrating into corresponding activities of their condition [18]. This knowledge will enable qualified interventions, the awareness and commitment of the whole civil and religious community. The holistic approach will be insisted on; the patients are considered not just sick bodies but people having feelings, needs, social and spiritual complexes. Socrates stipulated the inseparable connection between the two levels saying that "you cannot heal the body without soul" and Jesus Christ taught us that it is the duty of everyone to go together to the seniors. More than ever, the attitude of indifference, distrust and abandoning the active participation, or the joint responsibility of the society should be overcome. The care of elderly patients, those who cannot manage themselves and those who, due to the old age degradation have lost their mental faculties is also a spiritual care regarding the mediating signs of prayer and of faith proximity.

The palliative care gives value to life and so we consider death as a natural process of life: they neither rush nor postpone death but intend to maintain the best possible quality of life until death. Palliative 
Citation: Tamas I, Tamas C, Aginitei-Zbranca A, Poroch V (2016) Aging in the Holy Scripture: The Human Responsibility for the Elderly Grounded On Ontology and Bioethics. J Clin Res Bioeth 7: 1000283. doi:10.4172/2155-9627.1000283

Page 4 of 4

approach is an interdisciplinary type, the palliative team being made of the doctor, nurse, psychologists, social counselor, priest (if applicable) and other professionals in the field. These ensure such a support system that allows patients to live as actively as possible until death, to help families and patients to "live together" with the disease. Palliative care can be early established on the illness trajectory in parallel with other therapies (chemotherapy, radiotherapy, etc.) including both supportive treatment and the addressing of the terminal patient. Particularly impact of palliative care as well as the perspective by which they are considered the patients' and their families' right determined the international bodies to take measures to facilitate access to the best possible palliative care. Thus, the Council of Europe recommended that the Member States to adopt legislative policy and other measures necessary to formulate a national coherent and comprehensive legislative framework for palliative care and the World Health Organization adopted resolutions to improve their access to palliative care; since May 24, 2014 it asked the signatories Ministries of Health to limit and facilitate understanding of the incurable patients' suffering [19].

\section{Conclusions}

The article "Aging in the Holy Scripture: The Human Responsibility for the Elderly grounded on Ontology and Bioethics" has provided an analysis of lifetime useful to faithful people and those without this foundation. We followed the biblical understanding of the old age and the Catholic Church on the issue of grandfather and grandmother's care. We have provided a brief reflection on the skin aging which, during the last century, due to the medical discoveries and economic growth make people live longer and society to harder accept skin aging and the apparently passage of time. The dermatologist stands in front of a pathological phenomenon: to consider physiological aging as being abnormal and treat the consequences. Nowadays, skin benefits from care that would slow down the physiological pace of aging. Cosmetology has active principles that prevent, mitigate or slow its senescence marks. At this point knowing the requirements of an elderly person come into discussion, bioethical and ontological grounded a knowledge that will enable qualified interventions, the awareness and commitment of the entire civil and religious communities. As Christians and citizens, we are called to change, by fantasy and wisdom, the roads to face this challenge. One of the nicest things of family life is to comfort a child and this to be comforted by a grandfather or grandmother. The future of a people necessarily implies this meeting: the young give strength to make people go and the elders strengthen this force by the memory and wisdom of popular culture. It is therefore desirable to go through life with all its stages, with courage, picking its deeper meaning as a meeting way and as a gift between generations.

\section{References}

1. Stafford JA (1999) Demnitatea persoanei în vârstă şi misiunea sa în Biserică şi în lume. Consiliul Pontifical pentru Laici, Editura Presa Bună p. 3 .

2. Francis (2014) Evangelii gaudium. Editura Presa Bună p. 210

3. Bernal G (2013) Philosophical Anthropology as Key to Bioethics. Revista Română de Bioetică 11: 130-134.

4. Leone S, Privitera S (2004) Nuovo Dizionario di Bioetica. Citta Nuova p 455-459.

5. Ioan Paul al II-lea (1993) Scrisoare către bătâni. Editura Presa Bună p. 3 .

6. Bulai A, Patraşcu E (2013) Biblia. Sapientia.

7. Băltăceanu F, Broşteanu M (2001) Vocabular de teologie biblical. Editura Arhiepiscopiei Romano-Catolice Bucureşti 50-51.

8. (2001) Gaudium et Spes, Conciliul Ecumenic Vatican II. Editura Arhiepiscopiei Romano-Catolice 18.

9. (2007) Compendiu de Doctrină Socială a Bisericii. Consiliul Pontifical pentru Dreptate și Pace. Libraria Sapientia 222.

10. Kuby G (2014) Revoluţia sexuală globală. Sapientia p. 291.

11. Kuby G (2014) Etatizarea educaţiei. Sapientia p. 15.

12. Gavrilovici C, Oprea L (2013) Etica clinică etica cercetării şi etica comunitară-triada morală a societăţii contemporane. Revista Română de Bioetică 11: 3-5.

13. Gavrilovici C, Cojocaru D, Astărăstoae V (2012) Despre autonomie, vulnerabilitate şi fragilitate. Revista Română de Bioetică 10: 3-4.

14. (1993) Catehismul Bisericii Catolice. Editura Arhiepiscopiei RomanoCatolice 2218.

15. Hernandez M, Fresnel M-M (2006) Le nouveau precis d'esthetique cosmetique. Vigot Paris 309-311.

16. Hortolomei M, Popovici I, Ochiuz L (2012) Influence of formulation factors on the physico-chemical characteristics of dermal microemulsions prepared with sucrose esters. Farmacia 60: 484-492.

17. Ochiuz L (2011) Hidroxiacizii - materii prime importante în industria produselor dermatocosmetice. Practica farmaceutică 4: 167-178.

18. WJA Van del Heuvel, Marinela Olăroiu (2008) Ingrijirile Paliative în România: Necesităţi şi Drepturi. Revista Română de Bioetică 6: 57-62.

19. Alexa O, Veliceasca B, Malancea R, Alexa I (2013) Postoperative cognitive disorder has to be included within informed consent of elderly patients undergoing total hip replacement. Revista Română de Bioetică 11: 38-39. 